\title{
MEDIAÇÕES PEDAGÓGICAS NA INTERPRETAÇÃO DE EXPERIMENTAÇÕES INVESTIGATIVAS: UMA ESTRATÉGIA DIDÁTICA PARA A FORMAÇÃO DOCENTE EM QUÍMICA
}

\author{
Rosel Pacheco Schnetzler \\ Universidade Metodista de Piracicaba (Unimep), Piracicaba, São \\ Paulo, Brasil \\ Lenice Heloisa Arruda Silva \\ Universidade Federal da Grande Dourados (UFGD), \\ Dourados, Mato Grosso do Sul, Brasil \\ THIAGO AntunES-SOUZA \\ Universidade Metodista de Piracicaba (Unimep), \\ Piracicaba, São Paulo, Brasil
}

\begin{abstract}
Resumo: O presente trabalho propõe uma estratégia didática que articula a importância de mediações pedagógicas com a organização de ideias químicas envolvidas em um experimento, segundo os três níveis do conhecimento químico (fenomenológico, representacional e teórico-conceitual). Essa estratégia foi desenvolvida com trinta futuros professores de Química e a sua análise está apoiada na abordagem microgenética, buscando evidenciar a importância da interlocução professor-aluno como mediação de negociação de significados. Os resultados indicam que nestes processos, a palavra docente orienta, deliberadamente, o pensamento dos alunos, auxiliando-os no processo interpretativo da experiência e de sua mediação no processo de elaboração de conceitos químicos altamente abstratos.
\end{abstract}

Palavras-chave: Mediação Pedagógica. Experiência investigativa. Elaboração conceitual. Formação docente em Química. 
INTRODUÇÃO

A usual aula prática de Química, tanto no ensino médio quanto em cursos de formação de professores, centra-se na aprendizagem de procedimentos seguindo o estabelecido em roteiros experimentais e na elaboração de relatórios, desconsiderando que o mais importante na experimentação não é só fazê-la, mas sim, interpretá-la. Comumente proposta como motivadora para mostrar aos alunos a "comprovação" de teorias químicas, esta concepção de experimentação tem veiculado uma visão distorcida de Química (empiricista/positivista), pois a aula prática não tem a função de concretizar formulações teóricas, uma vez que ao tentar propor explicações para um fenômeno, os alunos estão testando a previsibilidade e generalidade de teorias e não apurando sua veracidade (SILVA; MACHADO; TUNES, 2010). Como diz Echeverría (1993, p. 175): “A descontinuidade da matéria, por exemplo, não é demonstrada pela prática que se realiza nos laboratórios das escolas. A ideia mais frequente que emerge da observação empírica é a de continuidade". Assim, a pesquisa em ensino de Ciências vem reivindicando à aula experimental mais ênfase na discussão e interpretação do fenômeno (HODSON, 1994; SILVA; ZANON, 2000; SILVA; MACHADO; TUNES, 2010). Portanto, tal atividade precisa promover a articulação teoria-experimento, pois como Souza et al. (2013, p. 13), defendemos que o professor estimule o aluno a pensar sobre o que está fazendo: “Não basta que o aluno manipule vidrarias e reagentes, ele deve, antes de tudo, manipular ideias (problemas, dados, teorias, hipóteses, argumentos)".

É nesta direção que Hodson (1994) propõe outro enfoque à experimentação - investigativo - que propicie aos alunos a exploração e a interpretação de fenômenos, incluindo a identificação e a reelaboração de suas ideias prévias. Deste modo, atividades experimentais investigativas são elaboradas com o objetivo de promover condições para que alunos consigam elaborar conceitos e desenvolver habilidades de raciocínio. A atividade investigativa parte, portanto, de um problema que incentive os alunos a buscar informações baseadas em conhecimentos científicos já adquiridos para solucionar a questão por meio de elaboração de hipótese, assim como Souza et al. (2013, p. 14) conceituam:

Além do reconhecimento de fenômenos, as atividades experimentais podem ter um alcance maior na formação do aluno, pois podem ser planejadas para proporcionar a elaboração de conceitos e o desenvolvimento de habilidades de pensamento relacionadas aos processos da ciência. 
Para tanto, é preciso questionar algumas crenças enraizadas entre a maioria dos professores de Química: i) de que a experiência por si só não promove a aprendizagem em nível microscópico; ii) repensar a função da experimentação no ensino de Química, objetivando explorar suas potencialidades no que se refere ao estabelecimento de articulações entre os três níveis do conhecimento químico: fenomenológico ou macroscópico (observações, medidas), representacional (fórmulas, equações/ linguagem química) e teórico-conceitual ou microscópico (modelos e teorias/ conceitos abstratos).

Tal articulação foi inicialmente proposta por Johnstone (1991) e enfatizada por vários educadores químicos, tendo por objetivo um ensino no qual o fenômeno, a linguagem e a teoria comparecem como aspectos igualmente importantes na aquisição de conhecimentos químicos escolares. Sobre tal modelo, Mortimer, Machado e Romanelli (2000) consideram que a abordagem experimental a partir da inter-relação dos três níveis de conhecimento pode mostrar uma forma de se conceber a Ciência como atividade em que a teoria e a realidade estão em constante interlocução mediada pela linguagem.

Assim, em oposição às aulas experimentais que enfocam aspectos macroscópicos em detrimento dos outros dois, compreendemos como essenciais os processos interativos e dinâmicos em que o professor faz intervenções deliberadas voltadas para elaboração de explicações e significações no nível teórico-conceitual. Tal atividade implica que professores promovam mediações pedagógicas, articulando conceitos teóricos que expliquem ou interpretem constatações fenomenológicas. A esse respeito, Silva e Zanon (2000, p. 135-136) apontam:

[...] reiteramos que é essencial, aos processos interativos e dinâmicos que caracterizam a aula experimental de ciências, a ajuda pedagógica do professor que, em relação não simétrica, faz intervenções e proposições sem as quais os alunos não elaborariam as novas explicações aos fatos explorados na sala de aula. Tal exploração não se baseia na observação empiricamente construída, mas sim, na problematização, tematização e conceitualização com base em determinados aspectos práticos/fenomenológicos evidenciados.

Nesse sentido, este trabalho destaca o papel assimétrico do professor na aprendizagem discente, ao estabelecer um processo dialógico em que deliberadamente orienta o pensamento do aluno (FONTANA, 1996). Em outras palavras, pretendemos evidenciar o quanto o(a) professor(a) é importante para promover no aluno a elaboração de ideias abstratas e generalizantes 
para interpretar o fenômeno observado, por meio de articulações mediadas por ele/ela entre aqueles três níveis de conhecimentos químicos.

Desta forma, considerando a carência de embasamento teórico de professores no que se refere ao papel da experimentação no ensino de Química, o presente trabalho analisa como mediações pedagógicas associadas à experimentação investigativa articulam os três níveis de conhecimentos químicos.

\section{REFERENCIAL TEÓRICO ADOTADO NA INVESTIGAÇÃO}

Pautando-nos em pressupostos da psicologia histórico-cultural, mais precisamente nos estudos liderados por Lev Vigotski ${ }^{1}$, bem como em contribuições do campo da linguística por meio dos estudos de Mikhail Bakhtin, consideramos a aprendizagem escolar como um processo alicerçado na interação dialógica entre os sujeitos presentes na sala de aula e caracterizado pela dinâmica entre pensamento e linguagem, em que o conceito científico é sempre mediado por outro conceito (FONTANA, 1996; FONTANA, CRUZ, 1997).

No processo de interação social, a linguagem adquire um lugar privilegiado como forma de comunicação entre os indivíduos que se apresentam como produtos históricos e significantes da atividade mental humana:"para agir coletivamente o homem teve que criar um sistema de signo que permitisse a troca de informações específicas e a ação conjunta sobre o mundo, com base em significados partilhados pelos indivíduos" (FONTANA; CRUZ, 1997, p. 83). Assim, mais do que comunicar, a linguagem desempenha um decisivo papel na atividade intelectual por ser constituinte do entendimento e da elaboração das experiências pessoais e da consciência de si mesmo. A palavra, na condição de um sistema simbólico, desenvolve-se "nas relações com o outro, nas nossas interações que ela vai sendo incorporada às nossas funções biológicas" (FONTANA; CRUZ, 1997, p. 83).

Ao designar ao signo uma função mediadora, Vigotski atribui à linguagem, especialmente à palavra como signo, um papel significativo na constituição do indivíduo humano como pessoa e na apropriação e elaboração de conhecimentos. Segundo ele, "as palavras desempenham um papel central não só no desenvolvimento do pensamento, mas também na evolução histórica da consciência como um todo. Uma palavra é um microcosmo da consciência humana" (VIGOTSKI, 2000b, p. 190). 
No campo da linguagem, numa perspectiva que também privilegia as relações sociais, Bakhtin (2014, p. 49) identifica o signo como constituinte fundamental do psiquismo subjetivo. Neste sentido, ele diz que:

A realidade do psiquismo interior é a do signo. Sem material semiótico, não se pode falar em psiquismo. [...] Por natureza, o psiquismo subjetivo localiza-se no limite do organismo e do mundo exterior, vamos dizer, na fronteira dessas duas esferas da realidade. É nessa região limítrofe que se dá o encontro entre o organismo e o mundo exterior, mas este encontro não é físico: o organismo e o mundo se encontram no signo.

Acrescenta, ainda, que:

[...] tudo que ocorre no organismo pode tornar-se material para a expressão da atividade psíquica, posto que tudo pode adquirir um valor semiótico, tudo pode tornar-se expressivo. Mas, o material semiótico privilegiado do psiquismo é a palavra. Ela está presente em todos os atos de compreensão e de interpretação, sendo o fundamento, a base da vida interior (BAKHTIN, 2014, p. 52).

Fundamentada no pensamento de Vygotski, Góes (2000a, p. 121) reitera essas ideias ao dizer que:

A palavra tem o poder de regular e conferir um caráter mediador entre as pessoas. As interações verbais internalizam-se, isto é, são reconstruídas no plano individual, transformando em funções psicológicas e criando a base para a estrutura social da personalidade. As funções psicológicas emergem no plano das relações sociais, e o indivíduo se constrói a partir delas.

Nessa perspectiva, as funções psicológicas superiores se configuram pela apropriação, pela (re)elaboração e pelo uso de recursos mediacionais semióticos (signos) internalizados, os quais não são criados pelo indivíduo e nem descobertos na sua relação direta com o objeto. Ele tem acesso a esses recursos pelo fato de fazer parte de um meio sociocultural. Assim, pelo caráter social dos signos, é na comunicação com o(s) outros(s), na interação social, que o indivíduo pode ter acesso, se apropriar e (re)elaborar formas culturais de pensamento e ação (WERTSCH, 1995).

Desse modo, o desenvolvimento do indivíduo é mediado socialmente pelo Outro e pelos signos, ou seja, o seu desenvolvimento vai se estabelecendo na dinâmica interativa ou no plano das interações. Ele torna sua as ações que inicialmente têm um significado partilhado. Tais ações 
ao serem internalizadas passam a constituir o funcionamento interno do sujeito, que desloca a fonte que era externa ou do(s) outro(s) para a autorregulação (GÓES, 2000a).

Vigotski entende, portanto, o plano intersubjetivo como o da relação do sujeito com o outro. O funcionamento interno é fruto da internalização das ações entre sujeitos, as quais se transformam para construir o funcionamento interno, consequentemente, não são cópias do plano externo. Assim,

[...] posto que há uma necessária interdependência dos planos inter-e intra-subjetivos, a gênese de seu conhecimento não está assentada em recursos só individuais, independentes da mediação social ou dos significados compartilhados. O sujeito não é passivo, nem apenas ativo: é interativo (GÓES, 1991, p. 21).

Ao conceber que o sujeito é interativo, Vigotski está assumindo os processos cognitivos como frutos de atividades mediadas pelo Outro e pelos signos, assumindo, também, a internalização como um processo inicialmente interpessoal que se transforma em intrapessoal (FONTANA, 1996). E, ao conceber o pressuposto de que toda função psicológica superior é uma relação social, Vigotski postula a lei genética geral de desenvolvimento cultural:

[...] toda função no desenvolvimento cultural da criança aparece em cena duas vezes, em dois planos; primeiro no plano social e depois no plano psicológico, em princípio entre os homens como categoria interpsíquica e logo no interior da criança como categoria intrapsíquica. $O$ dito se refere por igual à atenção voluntária, à memória lógica, à formação de conceitos e ao desenvolvimento da vontade (VIGOTSKI, 1995, p. 150).

Assim, Vigotski (1993), mesmo considerando a elaboração conceitual um processo integrado, destaca a identificação e diferenciação de dois tipos de conceitos: os cotidianos e os científicos. Os primeiros caracterizam-se pela mediação espontânea do adulto, em que ambos os sujeitos têm sua atenção voltada para o objeto ou situação concreta que vivenciam. Já os conceitos científicos, sistematizados, que aprendemos na escola, além da orientação deliberada do professor, têm como traço característico o uso funcional da palavra como instrumento de pensamento (a palavra tem o papel de signo mediador dos conceitos e de agente de generalizações e abstrações), isto é, a atividade intelectual é dirigida pelo próprio ato de pensamento (FONTANA; CRUZ, 1997). 
Portanto, ao considerarmos o desenvolvimento do pensamento e a elaboração de conceitos, torna-se importante evidenciar a função que a palavra, um signo, desempenha em tais processos. A esse respeito, Silva (2004, p. 47) apoiada em Vigotski, considera que:

[...] todas as funções psíquicas superiores são processos mediados socialmente, e os signos constituem o meio básico para o indivíduo humano aprender a organizar e desenvolver o seu próprio comportamento, pois o signo mediador é incorporado à sua estrutura como parte fundamental na sua constituição como sujeito. O mesmo acontece na formação de conceitos, que tem como signo mediador a palavra, a qual, em princípio tem a função de meio de formação de um conceito e, posteriormente, torna-se seu símbolo.

Isto nos remete ao conceito de mediação semiótica, assim expresso por Pino (1991, p. 33):

os seres humanos criaram instrumentos e sistemas de signos cujo uso lhes permite transformar e conhecer o mundo, comunicar suas experiências e desenvolver suas funções psicológicas. A mediação dos sistemas de signos constitui o que denominamos "Mediação Semiótica".

Deste modo, o processo de ensino-aprendizagem é alicerçado pela mediação feita pelo professor, a qual possibilita ao aluno a apropriação e elaboração de conhecimentos. Nesses termos, assumimos o processo de conceitualização em sala de aula como uma "prática social dialógica (mediada pela palavra) e pedagógica (mediada pelo outro)" (FONTANA, 1993, p. 3, grifos da autora).

Explicitando o que significa a mediação pedagógica e sua importância, trazemos o que expressa Pino $(1997$, p. 18) sobre o processo de apropriação e elaboração conceitual pelo sujeito. Segundo o autor, esse processo "não se explica nem como obra única da razão, nem como simples efeito da experiência sensível, nem ainda como resultado da interação direta entre sujeito e objeto". Isto porque o ato de conhecer é um tipo de atividade social que pressupõe uma relação entre três elementos: o sujeito que conhece, o objeto a conhecer e o elemento mediador, sendo, este último, aquele que torna possível o reconhecimento do objeto pelo sujeito, uma vez que, mesmo que este sujeito possua determinadas características que lhe permita apreender as particularidades do objeto, sem a mediação que lhe propicie a apropriação e elaboração de conhecimentos sobre o objeto, isso se torna impossível (PINO, 1997).

Assim, quando Vigotski atribui ao signo uma função mediadora, a palavra ganha um papel significativo na constituição e desenvolvimento do 
indivíduo humano e na apropriação e elaboração de conhecimentos. E, tal como Vigotski, Bakhtin (2014) atribui uma função especial à palavra e avança em direção à explicação de como as significações vão se constituindo na interlocução verbal.

Fontana (1996, p. 28), ao discorrer sobre a dimensão ideológica da elaboração conceitual, faz a seguinte ponderação:"Enquanto Vigotski procura traçar as possibilidades de elaboração no plano individual, Bakhtin analisa a dinâmica sócio-ideológica". Bakhtin (2014, p. 72) pensa a linguagem na esfera única da relação social organizada: "é preciso situar os sujeitos - emissor e receptor do som - bem como o próprio som, no meio social". E, com semeIhante interpretação à de Vigotski, não concebe a atividade consciente do homem fora da linguagem semiótica e da interação social:

Os signos só se emergem, decididamente, do processo de interação entre uma consciência individual e outra. E a própria consciência está repleta de signos. A consciência só se torna consciência quando se impregna de conteúdo ideológico (semiótico) e, consequentemente, somente no processo de interação social (BAKHTIN, 2014, p. 34).

Para além dos estudos de Vigotski, Bakthin considera o signo um produto ideológico, afirmando que tudo o que é ideológico tem um valor semiótico e vice-versa, pois, "tudo o que é ideológico possui um significado e remete a algo situado fora de si mesmo. Em outros termos, tudo o que é ideológico é um signo. Sem signos não existe ideologia" (2014, p. 31). Para Bakhtin (2014), os signos são considerados a materialização da comunicação social, e sobre a relação entre expressão e atividade mental, o autor nos revela que a atividade mental é sempre organizada pela expressão-enunciação. Aqui é importante destacar que a enunciação é concebida como produto da interação de dois indivíduos socialmente organizados e que é sempre determinada pela situação social mais imediata. Nesse sentido, a palavra se coloca como território comum entre locutor e interlocutor na medida em que:

Toda palavra comporta duas faces. Ela é determinada tanto pelo fato de que precede de alguém, como pelo fato de que se dirige para alguém. Ela constitui justamente o produto da interação do locutor e do ouvinte. Toda palavra serve de expressão a um em relação ao outro. Através da palavra defino-me em relação ao outro, isto é, em última análise, em relação à coletividade. A palavra é uma espécie de ponte lançada entre mim e os outros (BAKHTIN, 2014, p. 117). 
E, a partir desta concepção do que é a palavra, podemos considerar que a realidade fundamental da língua é constituída pelo fenômeno social da interação verbal. Vale destacar que, do modo como locutor e ouvinte estão organizados, não há uma única voz harmoniosa, já que todo discurso se faz face à polêmica (FONTANA, 1996).

É nesse processo de interlocução verbal que Bakhtin vai dimensionar o lugar da significação: esta só pertence à palavra no espaço da interlocução, ou seja, só se realiza no processo de interação ativa e responsiva.

A significação não está na palavra nem na alma do falante, assim como também, não está na alma do interlocutor. Ela é o efeito da interação do locutor e do receptor produzido através do material de um determinado complexo sonoro [...] Só a corrente da comunicação verbal fornece à palavra a luz da sua significação (BAKHTIN, 2014, p. 137).

Nesse processo dialógico, a produção de significados vai se construindo num jogo de confrontação permanente. O próprio modo de organização escolar nos diz muito sobre essas relações na elaboração de conceitos, afinal professor e aluno possuem papéis definidos - um o de ensinar e o outro o de aprender - numa dinâmica comunicativa em que o aluno vai tomando a palavra de professor e o significado da mesma vai evoluindo nesta interlocução.

O discurso, assim como o conceitua Pino (1991, p. 39), revela-se um processo que tem por traço característico a produção social de significação:

[..] pode-se concluir que a linguagem, sistema articulado de signos, construído socialmente ao longo da história, veicula significados instituídos relativamente estáveis, embora mutáveis, o que faz a polissemia das palavras. Entretanto esses significados adquirem significação concreta na interlocução.

Nesse sentido, a elaboração conceitual caracteriza-se como um processo discursivo em que a produção de significados vai se construindo num jogo de confrontação permanente de múltiplas vozes historicamente definidas (FONTANA, 1996). Afinal, como dizem Mortimer e Machado (1997, p. 140): "a construção do conhecimento em sala de aula depende essencialmente de um processo no qual os significados e a linguagem do professor vão sendo apropriados pelos alunos na construção de um conhecimento compartilhado". 


\section{As OPÇÕES METODOLÓGICAS}

A tentativa de apreender as mediações pedagógicas associadas à articulação dos três níveis de conhecimento durante a explicação de um experimento investigativo, explicitou a necessidade de uma perspectiva metodológica que permitisse não só evidenciar as características desse processo, mas, também, trabalhar dentro dele.

Na compreensão de Fontana (1996), um estudo dessa natureza caracteriza-se pela análise das condições concretas de atividade que, no caso da elaboração conceitual na escola, referem-se às relações de ensino. É em função do espaço ocupado pelos interlocutores, explícito pela relação ensinar/aprender, que a mediação do professor imprime marcas no processo de elaboração de conceitos.

[...] é exatamente a intencionalidade da ação pedagógica em relação à apropriação dos conceitos sistematizados e das práticas intelectuais a elas relacionadas que faz da educação escolarizada o lugar próprio da psicologia, ou seja, um lugar de aprendizagem da gênese de funções psicológicas (FONTANA, 1996, p. 30).

Com base nesse enfoque é que, no âmbito deste trabalho, analisamos como mediações pedagógicas associadas à experimentação investigativa podem articular os três níveis de conhecimentos químicos (fenomenológico, representacional e teórico-conceitual). O intuito é evidenciar o quanto o(a) professor(a) é importante para promover, nos alunos, a elaboração de ideias abstratas e generalizantes para interpretarem o fenômeno observado, por meio de articulações mediadas por ele/ela entre aqueles três níveis de conhecimentos químicos.

Tendo em vista o referencial teórico que fundamenta este trabalho, para os procedimentos metodológicos da investigação adotamos uma abordagem de análise microgenética, assim definida por Góes (2000b, p. 9):

De um modo geral, trata-se de uma forma de construção de dados que requer a atenção a detalhes e o recorte de episódios interativos, sendo o exame orientado para o funcionamento dos sujeitos focais, as relações intersubjetivas e as condições sociais da situação, resultando num relato minucioso dos acontecimentos.

Nesses termos, esta investigação implicou a escolha de um trabalho empírico em um contexto real de sala de aula, intentando destacar como o 
processo de elaboração de conceitos vai sendo orientado por uma professora na interlocução verbal com seus alunos. Para atender à abordagem da análise microgenética, que tem como traço característico uma "perspectiva de investigação da constituição do sujeito, concebida no âmbito dos processos intersubjetivos e das práticas sociais" (GÓES, 2000b, p. 21), as ocorrências em sala de aula, bem como as ações e diálogos entre a professora e seus alunos foram observados, descritos em caderno de campo, gravados em áudio e, posteriormente, transcritos e analisados.

O critério adotado para recortar os registros das aulas, exigiu, inicialmente, várias releituras das transcrições das observações e das gravações das aulas, no intuito de nos familiarizarmos com as informações e descrições obtidas sobre o processo de elaboração de conceitos. Procuramos identificar alguns episódios dentro desses registros para posteriormente selecioná-los e organizá-los.

A organização dos dados foi definida em função do que estamos considerando uma melhor visualização do processo de elaboração de conceitos. Isso inclui trechos de aula em que há enunciações, falas e entonações da professora que indicam elaborações, que refletem, em maior ou menor grau, esse processo. Inclui, também, trechos de aula na qual há falas da professora, questões colocadas para o desenvolvimento de um conceito, perguntas dos alunos que apontam para interações entre a professora e os alunos.

O episódio selecionado para análise faz parte de uma aula de uma disciplina pedagógica ministrada para estudantes concluintes do curso de Química-licenciatura de uma universidade confessional, situada no interior do Estado de São Paulo. A turma era composta por trinta licenciandos do sétimo semestre e a discussão ocorreu no primeiro semestre de 2015.

Ao longo do semestre, a professora havia trabalhado com os licenciandos questões a respeito da função da experimentação no ensino de Química e também promovido discussões sobre experimentos investigativos. $\mathrm{Na}$ atividade que gerou o episódio selecionado, o assunto a ser desenvolvido era a abordagem de uma experiência investigativa sobre mobilidade iônica nas reações químicas.

Nesta aula, a professora solicitou aos alunos que se dividissem em grupos de até três alunos cada e expôs o objetivo da atividade: ensinar como seus alunos, futuros professores de Química, poderiam abordar experiências investigativas por meio de mediações pedagógicas que levassem os seus futuros alunos a construir conceitos químicos altamente abstratos.

Essa aula fazia parte de um trabalho desenvolvido pela professora, que buscava demonstrar como levá-los a interpretar um experimento inves- 
tigativo, destacando as ideias químicas pertinentes para tal, e articulando-as segundo os três níveis de conhecimentos químicos (fenomenológico, representacional e teórico-conceitual).

Para o desenvolvimento de tal atividade, a aula organizou-se da seguinte forma: 1) a professora demonstrou o experimento e problematizou o fenômeno; 2) solicitou que os licenciandos respondessem às perguntas por ela levantadas, organizando suas ideias de acordo com os três níveis de conhecimentos químicos; 3) após um período de tempo de dez minutos para que os licenciandos realizassem tal tarefa, a professora discutiu o experimento, utilizando-se de questões que norteassem a atenção dos alunos para o fenômeno e retomando conceitos já conhecidos por eles; 4) após a interpretação do fenômeno a professora voltou à tabela dos três níveis de conhecimentos químicos preenchendo-a com os alunos.

Vale destacar que a escolha da professora se deu por sua disponibilidade para a investigação de sua própria prática docente, atendendo ao objetivo deste trabalho, e por ter formação em Educação Química, bem como experiência nesta área.

No episódio transcrito, a análise realizada baseia-se na contribuição dos pressupostos anteriormente assumidos, no sentido de se construir uma investigação de processos de elaboração de conhecimentos escolares que se dão no plano dos sujeitos envolvidos (Vigotski) e na dinâmica discursiva (Bakhtin).

\section{O EPISÓDIO SOB ANÁLISE}

Após explicitar o objetivo da aula, a professora representa um experimento na lousa, desenhando uma placa de Petri, e nela dizendo que adiciona água e, nas suas extremidades, uma pequena quantidade dos sais $\mathrm{KI}_{(\mathrm{s})}$ (iodeto de potássio) e $\mathrm{Pb}\left(\mathrm{NO}_{3}\right)_{2(s)}$ (nitrato de chumbo). Informa que, após alguns instantes, constata-se o aparecimento de um sólido amarelo no meio da placa, o que não ocorreu com o mesmo procedimento representado em um sistema fechado (frasco com tampa), sem adição de água. Sem mencionar que o precipitado amarelo é $\mathrm{Pbl}_{2(\mathrm{~s})}$ (iodeto de chumbo), a professora solicita aos alunos que expliquem o fenômeno, indicando quais representações químicas são possíveis e, principalmente, quais ideias teórico-conceituais são necessárias para explicar o fenômeno representado. Para tal, dez minutos foram dados à discussão em grupos de três alunos. Os diálogos que se seguiram são apresentados a seguir. 
(1) P: A primeira questão é o que se forma na placa de Petri?

(2) A1: lodeto de chumbo.

(3) P: Por que é iodeto de chumbo? Como você teria segurança para dizer que é isso?

(4) A1: Eu iria pela equação.

(5) P: Então se forma nitrato de potássio?

(6) P: Professores e professoras, como vocês explicariam, com segurança, que o precipitado é iodeto de chumbo? E aí A2, o que você acha?

(7) A2: Todos os nitratos são solúveis e a maioria dos sais de chumbo não são solúveis em água.

(8) P:Mas, como eu posso ter certeza? [Silêncio] Gente, vocês têm uma tabela de solubilidade de bases e sais. [a professora lê a tabela e fala das exceções de solubilidade de iodetos: prata, mercúrio e chumbo]. Então, como eu posso ter certeza se um sal é insolúvel em água? Eu olho na tabela de solubilidade. Quando eu considero os reagentes e penso nos possíveis produtos da reação, eu percebo que o nitrato de potássio não pode ser o precipitado porque ele é solúvel. Portanto, eu estou usando o conceito de solubilidade.

(9) P:Agora, para você formar iodeto de chumbo na placa de Petri, o que precisou acontecer?

(10) A1:Tem que ter meio aquoso.

(11) P: É? E o que o meio aquoso faz?

(12) A2: Acontece solubilização dos sais. O meio fica amarelo porque é onde os reagentes se encontram?

(13) P: Quem se encontram?

(14) A3: O iodeto de sódio e o nitrato de chumbo.

15. P. Mas quais são as espécies químicas que formam o iodeto de chumbo?

(16) A3: Ah, então é o iodeto e o chumbo?

(17) P: Íons iodeto e íons chumbo. E de onde vêm esses íons?

(18) A4: Do iodeto de potássio e do nitrato de chumbo que estão na água.

(1). P: Então o iodeto de potássio na água...

(20) Alunos: dissocia-se.

(21) P: E o que é dissociar?

(22) A4: Ele vira íon.

(23) P. Ele vira um íon???

(24) A1: Ele já era íon.

(25) P. Por quê? Vocês se lembram o que é uma ligação iônica? Então, você tem um metal alcalino que é o potássio e um halogênio que é o iodo, e que tem tendência a receber elétrons e o potássio tem tendência a ceder elétrons. lodeto de potássio é um sal, formado por ligações iônicas. Você já tem íons e eles estão na forma, professores, de cristal iônico. E qual é o papel da água?

(26) A3: Dissociá-los.

(27) P: E se romper esse cristal, o que vocês terão? O que acontece? [Silêncio] Eu posso pensar uma coisa assim [desenha a interação entre o iodeto e 
a molécula polar de água]. Como se chama esse íon? [Silêncio] É um íon solvatado, as moléculas de água ficam em torno dos íons. Qual o conceito que estamos usando?

(28) A2: Solvatação.

(29) P: Isso, então a primeira ideia foi de dissociação iônica que é o papel da água de romper os cristais iônicos e agora solvatação. $A 3$, agora vamos começar a representar a dissociação iônica dos sais, qual equação representa a dissociação? [A3 indica a dissociação iônica]. Então eu represento a equação somente com os íons chumbo e iodeto. Os íons potássio e nitrato permanecem em solução. E o que foi fundamental para que isso ocorresse?

(30) A2: Meio aquoso?

(31) P: Somente o meio aquoso? O que precisou acontecer para formar o precipitado?

(32) A4: Dissociação

(33) P: Dissociar é separar, só isso é suficiente?

(34) A3:É preciso contato entre os íons. Quando eles se dissociam eles começam a se espalhar pela água, não é?

(35) [a professora pede para um aluno, do fundo da sala, vir abraçá-la]

(36) P: O que precisou acontecer para ele vir [o aluno] até aqui?

(37) A3: Andar?

(38) P. Mobilidade. A reação ocorre devido à mobilidade iônica.

(39) A professora organiza o quadro final:

\begin{tabular}{|c|c|c|}
\hline Fenomenológico & Representacional & Teórico-conceitual \\
\hline $\begin{array}{l}\text { Formação de } \\
\text { precipitado amarelo. }\end{array}$ & $\begin{array}{l}\mathrm{KI}(\mathrm{s}) \rightarrow \mathrm{K}^{+}{ }_{(\mathrm{aq})}+\mathrm{I}_{(\mathrm{aq})} \\
\mathrm{Pb}\left(\mathrm{NO}_{3}\right)_{2(\mathrm{~s})} \rightarrow \mathrm{Pb}^{2+}{ }_{(\text {aq) }} \\
+2 \mathrm{NO}_{3 \text { (aq) }}^{-} \\
\mathrm{Pb}^{2+}{ }_{\text {(aq) }} 2 \mathrm{I}_{\text {(aq) }}^{-} \rightarrow \mathrm{Pbl}_{2(\mathrm{~s})}\end{array}$ & $\begin{array}{l}\text { Solubilidade; } \\
\text { Ligação iônica; } \\
\text { Dissociação lônica; } \\
\text { Solvatação; } \\
\text { Mobilidade lônica. }\end{array}$ \\
\hline
\end{tabular}

(40) P: Esse tipo de experimento ajuda a construir a ideia de mobilidade iônica, pois se o precipitado apareceu no meio da placa, isso evidencia que os íons se movimentam. Alguma dúvida?

(41) A5: Sim, por que não deram uma aula assim no começo do curso?

(42) P: É bom começar a perceber, antes tarde do que nunca, que o objetivo da experiência é ser interpretada, explicada, mobilizando a teoria. Orientando o pensamento do aluno pela teoria.

A simples leitura do episódio evidencia a importância da professora formular perguntas instigantes, dirigindo o pensamento de seus alunos para a construção do que ela pretendia: como estabelecer mediações pedagógicas na interpretação de experimentações investigativas visando a construção de conceitos químicos. No caso particular, o de mobilidade iônica. 
Nesse processo, a professora estabelece um jogo de confrontação permanente entre ela e seus alunos, como pode ser observado nos turnos 1 , $3,5,9,11,15,17,21,23,31,33$ e 36 . Em seus questionamentos, a professora evidencia que tenta dirigir, deliberadamente, o pensamento deles, sendo que tal orientação instiga um jogo dialógico em que há a confrontação de vozes historicamente definidas (FONTANA, 1996). Ou seja, na sua função docente, ela ressignifica, explicita e sistematiza conceitos químicos.

A importância dessa ação da professora reside no fato de que "os conceitos não são analisados como categorias intrínsecas da mente, nem como reflexo da experiência individual, mas sim,como produtos históricos e significantes da atividade mental mobilizada a serviço da comunicação, do conhecimento e da resolução de problemas" (FONTANA, 1996, p. 14). Assim é que nos turnos 5 e 23 ela questiona, respectivamente, a visão simplista do aluno de pensar a transformação química como uma mera dupla troca e o próprio significado de ligação iônica.

Nesse sentido, considerando que os conceitos científicos no contexto escolar são apropriados e reelaborados na interação professor-aluno pela mediação pedagógica, a professora procura corrigir a linguagem do aluno (17) e sistematizar os conceitos de solubilidade (8), ligação iônica (25), solvatação (27) e dissociação iônica (29), estabelecendo interlocuções com seus alunos que levam ao compartilhamento de significações conceituais adequadas.

Consideramos que a produção de significados vai se construindo face à polêmica, numa dinâmica comunicativa em que os alunos vão tomando a palavra da professora e o significado da mesma vai evoluindo nesta interlocução (BAKHTIN, 2014).

Por sua vez, os turnos 8, 25 e 27 evidenciam mediações da professora em direção à elaboração de um conceito por meio de outro conceito, ao invocar as ideias de solubilidade, ligação iônica e solvatação de íons para enfatizar o papel da água como essencial à elaboração do conceito de mobilidade iônica, sistematizado por ela nos turnos 38 e 40. Promove, assim, a elaboração de conceitos, cada vez mais generalizantes e abstratos, pela interpretação microscópica do fenômeno.

No que tange ao uso da representação simbólica via equações químicas, nos turnos 29 e 39, ao ir significando a representação da dissociação iônica, a professora possibilita a sistematização do conceito por meio da linguagem química. Assim, esta se torna, primeiro, um signo mediador que vai orientar o pensamento do aluno e, posteriormente, um signo deste conceito (MACHADO, 2000). Como entende Vigotski (1993), na formação de 
conceitos o signo mediador é a palavra, a qual tem, em princípio, a função de meio na formação de um conceito e, posteriormente, torna-se o seu símbolo. Finalmente, ao organizar as ideias químicas envolvidas na experimentação nos três níveis do conhecimento químico (turno 39), a professora evidencia a importância dessa articulação, contribuindo para minar a concepção de que a experimentação comprova a teoria, bem como para exemplificar o que significa interpretar um experimento.

Das análises até aqui feitas, podemos depreender que as mediações pedagógicas da professora centraram-se na: i) orientação deliberada da atenção do aluno por meio de perguntas; ii) elaboração de um conceito por meio de outro conceito; iii) sistematização do conceito por meio da linguagem química; iv) articulação dos três níveis do conhecimento químico. Justificando tais mediações, reforçamos que os conceitos científicos são considerados por Vigotski como uma forma superior de pensamento no qual a palavra é um meio para o desenvolvimento de operações intelectuais conscientes. Tais conceitos são impossíveis sem o uso funcional da palavra como signo mediador: "[...] o central neste processo é o uso funcional do signo ou da palavra como meio através do qual o adolescente domina e dirige suas próprias operações psíquicas, controlando o curso de sua atividade e orientando-a para resolver a tarefa que está posta" (VIGOTSKI, 1993, p. 132).

Além disso, ao analisarem as relações escolares, Fontana e Cruz (1997, p. 111) caracterizam a escola como um espaço em que professor e aluno interagem numa relação social específica: o professor com o papel social de ensinar e o aluno o de aprender. Todavia, tal relação não é tão simples na medida em que o aluno "é colocado diante da tarefa de compreender as bases dos conceitos sistematizados ou científicos; o professor é encarregado de orientá-lo".

\section{Considerações Finals}

Visando contribuir com sugestões para a melhoria da formação docente em Química e, consequentemente, para o seu ensino, este trabaIho propõe uma estratégia didática para o tratamento de experimentações investigativas, enfocando mediações pedagógicas e articulações entre os três níveis do conhecimento químico (fenomenológico, representacional e teórico-conceitual).

Fundamentando a importância de mediações pedagógicas em contribuições teóricas de Vigotski, Bakhtin e seguidores, procuramos evi- 
denciar a necessidade de se estabelecer, em sala de aula, a negociação de significados via interações discursivas professor-alunos, nas quais a palavra tem função fundamental por ser mediadora do pensamento e, portanto, do processo de elaboração conceitual por parte do aluno. Aliando a isso a organização de ideias químicas envolvidas na experimentação, segundo os três níveis do conhecimento químico, procuramos evidenciar a importância de considerá-los e sistematizá-los para a devida interpretação do experimento que, em termos didáticos, é proposto para mediar o processo de elaboração do conceito de mobilidade iônica, altamente abstrato, por parte dos alunos.

No entanto, como o experimento não fala por si e, também, não se serve a comprovações teóricas, procuramos combater tal concepção junto a futuros professores, enfatizando a importância da experimentação investigativa no ensino de Química e propondo uma estratégia didática que leve à sua interpretação, promovendo o processo de elaboração conceitual que é crucial para a aprendizagem do aluno. Nesse sentido é que podemos entender a importância do que é expresso pelo aluno e pela professora nos turnos 41 e 42 que finalizam o episódio aqui analisado.

Artigo recebido em: 19/06/2016

Aprovado para publicação em: 09/09/2016

\section{PEDAGOGICAL MEDIATIONS IN INTERPRETATION OF INVESTIGATIVE EXPERIENCES: A DIDACTIC STRATEGY FOR CHEMISTRY TEACHER EDUCATION}

ABSTRACT: This research proposes a didactic strategy aiming to articulate pedagogical mediations with an organization of chemical ideas involved in an experiment, according to the three levels of chemical knowledge: phenomenological, representational and theoretical. This strategy was developed with thirty future chemistry teachers and its analysis is supported by microgenetic approach aiming to highlight the importance of teacher-student dialogue in the mediation of meaning negotiation. The results indicate that in these processes, the teacher's word deliberately guides the thinking of the students, helping them in the interpretative process of the experience and mediating the development of highly abstract chemical concepts.

KeYwords: Pedagogical mediation. Investigative experience. Conceptual development process. Chemistry teacher education. 
MEDIACIONES PEDAGÓGICAS EN LA INTERPRETACIÓN DE EXPERIENCIAS INVESTIGATIVAS: UNA ESTRATEGIA DIDÁCTICA PARA LA FORMACIÓN DEL PROFESORADO DE QUÍMICA

RESUMEN: El presente trabajo propone una estrategia didáctica que articula la importancia de las mediaciones pedagógicas con organización de ideas químicas involucradas en un experimento, según los tres niveles del conocimiento químico (fenomenológico, representacional y teórico-conceptual). Esta estrategia fue desarrollada con treinta futuros profesores de Química y su análisis se apoya en el enfoque microgenético, con el objetivo de evidenciar la importancia de la interlocución profesor-alumno como mediación de negociación de significados. Los resultados indican que en estos procesos, la palabra docente orienta, deliberadamente, el pensamiento de los alumnos, auxiliándolos en el proceso interpretativo de la experiencia y de su mediación en el proceso de elaboración de conceptos químicos altamente abstractos.

Palabras-clave: Mediación Pedagógica. Experiencia Investigativa. Elaboración Conceptual. Formación Docente en Química.

\section{NOTAS}

1) Nesse estudo, optamos por empregar a grafia Vigotski, todavia, de acordo com as referências citadas poderão ser apresentadas outras grafias.

\section{REFERÊNCIAS}

BAKHTIN, M. (VOLOCHINOV, V. N.). Marxismo e Filosofia da Linguagem. Tradução: Michel Lahud e Yara Frateschi Vieira. São Paulo: Hucitec, 2014.

ECHEVERRÍA, A. R. Dimensão empírico-teórica no processo de ensino-aprendizagem do conceito de soluções no ensino médio. 1993. 183f. Tese (Doutorado em Educação) Faculdade de Educação da Universidade Estadual de Campinas (Unicamp), Campinas, 1993.

FONTANA, R. A. C. A elaboração conceitual: a dinâmica das interlocuções na sala de aula. In: SMOLKA, A. L.; GÓES, M. C. R. (Org.). A linguagem e o outro no espaço escolar. Campinas: Papirus, 1993.

. A mediação pedagógica na sala de aula. Campinas, SP: Autores Associados, 1996.

$\therefore$ CRUZ, M. N. Psicologia e trabalho pedagógico. São Paulo: Atual, 1997.

GÓES, M. C. R de. A natureza social do desenvolvimento psicológico. Cadernos CEDES, Campinas, n. 24, p. 17-24, 1991. 
. A formação do indivíduo nas relações sociais: contribuições teóricas de Lev Vigotski e Pierre Janet. Educação \& Sociedade, Campinas: CEDES, n. 71, p. 116-131, 2000a.

. A Abordagem microgenética na matriz histórico-cultural: Uma perspectiva para o estudo da constituição da subjetividade. Cadernos CEDES, Campinas, n. 50, p. 21-29, 2000b.

HODSON, D. H. Un enfoque más crítico del trabajo de laboratório. Enseñanza de Las Ciências, v. 12, n. 3, p. 299-313, 1994.

JOHNSTONE, A. H. Why is Science difficult to learn? Things are seldom what they seem. Journal of Computer Assisted Learning, v. 7, p. 75-83, 1991.

MACHADO, A. H. Pensando e Falando sobre fenômenos químicos. Revista Química Nova na Escola, n. 12, p. 38-42, nov. 2000.

MORTIMER, E. F.; MACHADO, A. H. Múltiplos olhares sobre um episódio de ensino: por que o gelo flutua na água? In: Encontro sobre teoria e pesquisa em ensino de ciências: linguagem, cultura e cognição reflexões para o ensino de ciências, 1997, Belo Horizonte. Anais... Belo Horizonte: UFMG-FE / UNICAMP-FE, 1997. p. 139-162.

; MACHADO, A. H.; ROMANELLI, L. I. A proposta curricular de química do estado de Minas Gerais: fundamentos e pressupostos. Química Nova, v. 23, n. 2, p. $273-$ 283, 2000.

PINO, A. O conceito de mediação semiótica em Vygotsky e seu papel na explicação do psiquismo humano. Cadernos CEDES, Campinas, n. 24, p. 32-43, 1991.

. O biológico e o cultural nos processos cognitivos. In: Anais [do] Encontro sobre Teoria e Pesquisa em Ensino de Ciências: linguagem, cultura e cognição; reflexões para o ensino de ciências. Belo Horizonte - MG, 05 a 07 de março de 1997, p. 05-24.

SILVA, L. H. A.; ZANON, L. B. A experimentação no ensino de Ciências. In: SCHNETZLER, R. P.; ARAGÃO, R. M. R. de (Org.). Ensino de Ciências: fundamentos e abordagens. Campinas: R. Vieira Gráfica e Editora Ltda., 2000, p. 120-153.

SILVA, L. H. A. Modos de mediação de um formador de área científica específica na constituição docente de futuros professores de Ciências/Biologia. 2004. 129 f. Tese (Doutorado em Educação) - Programa de Pós-Graduação em Educação da Universidade Metodista de Piracicaba (UNIMEP), Piracicaba, São Paulo, 2004, p. 36-64.

SILVA, R. R. de; MACHADO, P. F. L.; TUNES, E. Experimentar sem medo de errar. In: SANTOS, W.; MALDANER, O. A. (Org.). Ensino de Química em foco. Ijuí, RS: Editora Unijuí, 2010, p. 231-1.

SOUZA, F. L. de; et al. Atividades experimentais investigativas no ensino de química. São Paulo: Centro Paula Souza - Setec/MEC, 2013.

VIGOTSKI, L. S. Obras escogidas II: problemas de psicología general. Madrid: Visor, 1993. 
. Obras escogidas III: problemas del desarollo de la psique. Madrid: Visor, 1995. 2000a.

. A construção do pensamento e da linguagem. São Paulo: Martins Fontes,

. VYGOTSKY, L. S. Pensamento e Linguagem. São Paulo: Martins Fontes, $2000 \mathrm{~b}$. WERTSCH, J. V. Vygotsky y La formación social de la mente. Barcelona: Paidós, 1995.

Rosel PACHeco Schnetzler: Licenciada, bacharel em Química e especialista em Fotoquímica Orgânica pelo Instituto de Química da USP, São Paulo. Mestre em Metodologia de Ensino pela Faculdade de Educação da UNICAMP. PhD em Educação Química pela Universidade de East Anglia, Inglaterra. Docente da Faculdade de Educação da UNICAMP (1977-1996) e professora titular do Programa de Pós-Graduação em Educação da Universidade Metodista de Piracicaba (UNIMEP) desde 1997.

E-mail: rpschnet@unimep.br

Lenice Heloisa Arruda Silva: Licenciada em Ciências Biológicas pela Universidade Federal de Mato Grosso do Sul, Doutorado em educação pela Universidade Metodista de Piracicaba (2004). Professora Adjunta da Universidade Federal da Grande Dourados. Professora do Mestrado em Ensino de Ciências da Universidade Federal de Mato Grosso do Sul.

E-mail: leniceheloisa@smail.com

ThIAgO Antunes-SOUZA: Licenciado em Química pela UNIMEP (Universidade Metodista de Piracicaba) e doutorando do Programa de Pós-Graduação em Educação da mesma instituição.

E-mail: ths.asouza@gmail.com 